\title{
THE EFFECT OF THE CRITICAL PERIOD FOR ACQUIRING THE SECOND LANGUAGE
}

\author{
Ulmasbaeva Malika Alisherovna, \\ National Institute of Fine Arts and Design named after Kamoliddin Bekhzod, \\ Head of Department of "Languages and Literature" \\ MA student of Webster University \\ Email: malikakhoni@mail.ru
}

\begin{abstract}
There are many factors, which effects on Second language acquisition, such as cognitive development, cultural background, personal abilities, motivation, socioeconomic background, age and the level of native language acquisition. One of the important factors, which influence second language acquisition, is the age factor. Many types of research have been performed in order to trace the relations between the age and second language acquisition. However, the question remains to what extent age is important. The concept of the critical period for acquiring the second language associated with multiple hypotheses. Some researchers have focused on the fact that younger students are better learners, while others consider older students to be better learners. However, there are different views on how children and adults learn a foreign or second language. Some researchers believe that adults can easily get a second language due to their high cognitive level, clear logical analysis and strong ability to control themselves, while others find that acquiring a second language for adults is very difficult for many uncertain factors. Adults naturally find themselves in situations that require a more complex language and the expression of more complex ideas, while children lack pressure and maturity in the process of learning a second language. This article attempts to explore and analyze the study of age-based critical period hypothesis, and other relevant variables.

Key words: second language acquisition, age factor, critical period hypothesis, puberty, language environment, LAD.

\section{Introduction}

There are many factors, which effects on Second language acquisition, such as cognitive development, cultural background, personal abilities, motivation, socioeconomic background, age and the level of native language acquisition. One of the important factors, which influence second language acquisition, is age factor. Many researches have been performed in order to trace the relations between the age and second language acquisition. However, the question remains to what extent the age is important.
\end{abstract}


The concept of the critical period for acquiring the second language associated with multiple hypotheses. Some researchers have focused on the fact that younger students are better learners, while others consider older students to be better learners. However, there are different views on how the children and adults learn a foreign or second language. Some researchers believe that adults can easily get a second language due to their high cognitive level, clear logical analysis and strong ability to control themselves, while others find that acquiring a second language for adults is very difficult for many uncertain factors. Adults naturally find themselves in situations that require a more complex language and the expression of more complex ideas, while children lack pressure and maturity in the process of learning a second language. This article attempts to explore and analyze the study of age-based critical period hypothesis, and other relevant variables.

\section{Literature Review}

The first hypothesis is that younger learners are better than older language learners in SLA. This notion was highly supported by several researchers.

The idea of the existence of a critical period for learning the language, which ceases before puberty, was promoted by Canadian brain surgeon Penfield and Roberts (1959). Penfield suggests that the brain Plasticity of a child makes for superior ability, especially in acquiring units of language. According to Penfield, the best period to start teaching a second language was between 4 and 10 .

Lenneberg (1967), recognized as the "father" of the critical period, argues that language acquisition is an innate process, determined by biological factors that limit the critical period for language acquisition from two years to puberty. He also argues that the end of the critical period coincides with the process of lateralization, the process by which the two sides of the brain develop specialized functions. Later, researchers further identified a weak and strong version of CPH (Singleton and Ryan 2004). A weaker version states that the acquisition of a language should begin in a critical period and that, rather, the acquisition of a language will begin after the onset of a critical period, the more effective it will be. A stronger version claims that even if language learning begins in a critical period, it does not continue beyond the end of that period.

David Singleton (1989) proposed several proposals for the acquisition of age and a second language. The most popular are "younger = better" and "older = better" (Singleton, p. 31). He based on previous studies and studies on the age factor, focused on the skills of pronunciation of students and other language features. There are a number of studies to support the "younger better" hypothesis. Yamanda et al. (qtd. in Singleton, 1989) studied 30 Japanese primary school students aged seven to ten years. These students had no previous experience in English. The researchers used a list of 40 
English words and recorded the speed of student success. Their conclusion was that more than the average age of older students decreased with age, that is, the older the age, the lower the score.

Some adolescents or adults who begin to learn a second language will not be able to achieve proficiency in the language, while children who are exposed to a second language at an early age seem to speak as a native speaker (cf. Lenneberg 1967). In addition, language environments play an important role when students learn a foreign language.

In addition, Mark S. Patkovski (Mark S. Patkowski, 1982) conducted a study on 67 highly educated immigrants to the United States from different backgrounds. His results showed a strong negative relationship between the age of arrival and the syntactic rating. He concluded that the pre-puberty group studies language better than the group after puberty. He further turned to:

...the only factor which was highly associated with the level of syntactic proficiency attained by learners was the age at which acquisition of English began. Practice and instructional variables showed little or no association with the dependent variables. The result, then, appeared to strongly support the hypothesis of an age-related limitation on the ability to acquire full command of a second language. (Patkowski, 1982, p. 59)

Susan Oyama (1976) studied 60 men Italian immigrants who entered the United States between the ages of six and 20. The youngest races performed the better accent. She showed the relation of age and listening comprehension as follows:

...those subjects who began learning English before age 11 showed comprehension score similar to those of native speakers, whereas later arrivals did less well; those who arrived after the age of 16 showed markedly lower comprehension scores than the native. (Oyama, 1982, p. 23)

Another study of immigrants appeared in support of the "younger better" hypothesis. Johnson and Newport (1989) selected 46 Chinese and Korean experimental subjects in their research. They examined some of the rules of English morphology and syntax among participants in the age groups from three to fifteen, as well as with those age groups from 17 to 39 . As a result, those who began to study later did not have native like accent, as well as their ability to test ranged more widely.

A second strong hypothesis is that older students are more successful than younger learners in SLA. This concept was highly appreciated by a number of shortterm experimental researchers. These studies and research were based on educational projects and programs of the second immersion. In some of these studies, adolescents and adults of different ages were noted, where the results showed that older students are much better than younger ones. 
One of the studies conducted by Olsen and Samuels (1973) found that the performance of American English-speaking adults and adolescents was significantly better than children, after 15-25-minute German pronunciation sessions.

Twenty adult, native speakers of English were given 18 hours of intensive instruction in the pronunciation of Chinese and Japanese by Neufeld (1977). The purpose of the study was to test the 'nativeness' of their pronunciation. An imitation test was given to the learners and their utterances were judged on a five-point scale by native speakers of two languages. Nine subjects for Japanese and eight for Chinese had acquired native-like pronunciation. The result of the study suggests that under right conditions even adults can achieve native ability in pronunciation, a finding which runs counter to the Critical Period Hypothesis.

In another significant study on the issue of age in SLA, Birdsong (1992) found no evidence of any notable differences between the groups that were used for the experiments conducted by Coppieters (1987). A modified replication study was conducted, and based on the results, it was concluded that there were no significant differences between the performance of French and L2 learners of the language. Another research (1992) conducted by Birdsong showed that there was no evidence of any marked differences between 20 English-speaking learners of L2 French, who were near native in their oral ability, and 20 native speakers of French. The 'think-aloud' data from the participants were collected when performing their grammaticality judgment task. The findings of the study indicate that some learners who start learning L2 after puberty can also attain native-like proficiency.

Birdsong (2006) points out the prevalence of a widespread belief that native-like attainment by late L2 learners is confined to one or few tasks and moreover, an individual, whose language learning starts late in his/her life will not display native likeness across a variety of linguistic behaviors. This notion has been referred to as the 'Joseph Conrad effect'. Recent research studies, however, suggest that the attainment of nativelikeness among late L2 learners is possible.

The advantages of adults' second language acquisition exist objectively, adults' cognitive level, logical analysis and self-monitoring abilities are higher than those of children. Krashen pointed out that if receiving time is the same, adults can also easily acquire a second language, and adults always make progress faster than children (Krashen and Stephen, 1982). Ellis also believes that adults have advantages in acquiring a second language (Ellis, 2013).

\section{Participant profile}

Subject is a 41-year-old Uzbek/Russian bilingual speaker, who learned English as a second language. He started learning English when he was 15, after puberty. His English fluent and he has native-like accent. 
His interest in learning English after receiving several audiocassettes with western music which had a lyric as a paper attachment to that tapes. His attitude to western culture and his desire to know what those music text meant motivated him to learn the language. He used to read and translate lyrics (words) and that is how his vocabulary started to grow. At age of 17 he entered to university with the international faculty in our country, where lectures were given in English language by native speakers. There was a tutor who only spoke to them in English, there were not too much of grammar at that time, they were getting more listening and reading. Major subjects were also given in English language where he could also practice listening comprehension and writing skills by making quick notes. As most of the exams where taken as a multiple choice, there was no need to have good speaking and writing skills to pass exams.

After he finished bachelor's degree and submitted to master's degree by passing TOEFL exam. At that time, he bought TOEFL preparation book written by Cliffs. That book was giving grammar in a very simple and clear style. It took him 2 weeks to read that book through and 2 extra weeks to prepare for exams. That is how he improved his grammar. He passed exams with the high score on TOEFL and entered to University in UK. When he got into UK, he realized that he didn't understand British accent, it was absolutely different from what he heard on BBC. And also, he realized that his speaking was too poor. So, it was a hard time for him until he had got his speaking and listening improved. It took him about 3 months to become fluent in English as he had no choice because was surrounded by British students and lecturers.

\section{Research design}

To collect necessary data, I interviewed my subject to find out about his learning trajectory and some learning difficulties he met. According his words he started learning English after puberty, which supports the claim, that some learners can also attain native-like proficiency. Age-related factors, such as learning opportunities, motivation to learn, individual differences and learning styles, are also important for determining variables that affect the rate of learning a second language at different stages of student development.

Furthermore, other factors have also a very strong impact on language acquisition. Many authors argue that environmental and social factors have a very large influence on the success of a study. Since my subject lived in a language environment and had the opportunity to constantly listen to the target language. In addition, some experts believe that high school students have the best linguistic competence and they have the best opportunities to solve problems and, thus, they can achieve better results when acquiring a language. Different aspects of the language are perceived differently in different age categories. Early students show better results in 
learning pronunciation, while older students learn grammar and syntax better. Language potential is another factor that has an important influence on the acquisition of a second language. Some people have a natural ability to learn a language, while others do not, and these trends are only reinforced by age factors.

Interview included following questions (internet source):

1. Describe your learning experience. Was it difficult for you to learn English? What was it that makes it most difficult for you?

2. In terms of speaking, listening, reading, and writing, in which aspect do you think you have made most progress since your arrival to UK? Do you think you have favorable learning conditions to learn English? What obstacles have you experienced in learning English?

3. How long do you think it took for you to be able to speak English fairly fluently? What do you consider the best method to improve your oral English? Do you think oral English is better learned through use or by rote?

4. How would you rate your memory? Are you able to remember what you have learned in class and use it in social contexts? Do you think age is a factor in learning a second language? If yes, in what way?

\section{Data Collection and Findings}

Researchers have begun to explore what advantages bilingualism can have in the process of learning a third language. They found that students who know two languages have an easier time gaining command of a third language than students who are fluent in only one language. My case study definitely supports this idea.

Although earlier studies suggest that age is an important influential factor in gaining complete SLA competence, motivation seems to be key element in the learning process. My subject was self-motivated to learn English. The term motivation was brilliantly bolstered in 1985 by Gardner who defined motivation as being "the combination of effort plus desire to achieve the goal of learning the language plus favorable attitudes toward learning the language" (p. 10). There are two motivational factors integrative and instrumental motivation (Gardner and Lambert 1972). First, he (my subject) had integrated motivation, as explained by Shirbagi (2010) are those learners who want to culturally interact with other community members and are willing to participate as valuable members of the target language country. When he wanted to pass TOEFL exams he had instrumental motivation, he wanted to learn a foreign language for educational purpose and seeking work opportunities in UK (Gardner and Lambert 1972).

Furthermore, other factors have also a very strong impact on language acquisition. A lot of authors state that surrounding and social factors have a very important impact on the study success. As my subject lived in the language environment and had an opportunity to hear the target language all the time. In 
addition, some specialists believe that older learners have better language competency and have better abilities for problem solving and thus can achieve better results in language acquisition.

\section{Conclusion}

As a conclusion I can say, that age is not everything in second language learning. However, factors related to the age, for example the learning opportunities, the motivation to learn, individual differences, and learning styles, are also important determining variables that affect the rate of second language learning in various developmental stages of the learners. In addition, surrounding and social factors have a very important impact on the study success. Motivation and interest to sound like the native speakers are the key factors that facilitate language learning, and therefore even adult learners can attain native-like proficiency. As our course book author, H.Douglas Brown (2014) mentioned:

...it is important to remember... that pronunciation of a language is not by any means the sole criterion for acquisition, nor is it the most important one. We all know people who have nonnative pronunciation but who nevertheless have excellent and fluent control of a second language, control that can even exceed that of many native speakers. The acquisition of the communicative and functional purpose of language is more important than a "perfect" native accent - unless of course you're planning to be an undercover spy in a foreign country! (Brown, H.D. 2014, p.59) 
References

Birdsong, D. (1992). Ultimate attainment in second language acquisition. Language, 68, 706-755.

Birdsong, D. (2006). Age and second language acquisition and processing: a selective overview. Language Learning, 56 (Suppl. 1), 9-49.

Brown, H. D. (2014) Principles of Language Learning and Teaching. (6th ed.) White Plains NY: Longman.

Cook, V. (2001).Requirements for a multilingual model of language production. Retrieved from homepage.ntlworld.com/vivian.c/Writings/Papers/RequirementsForMultilingualMo del.htm

Gardner, R. C., \& Lambert, W. E. (1972). Attitudes and motivation in secondlanguage learning. Rowley, Mass: Newbury House Publishers.

Johnson, J.S., \& Newport, E.L. (1989). Critical period effects in second language learning: The influence of maturational state on the acquisition of ESL. Cognitive Psychology, 21(1)

Krashen S., Long, M. and Scarcella, R. (1979) Age, rate and eventual attainment in second language acquisition. TESOL Quarterly 13, 573-82 Reprinted in S.

Krashen, R., Scarcella and M. Long (eds) (1982) Child-Adult Differences in Second Language Acquisition, Rowley, MA: Newbury House. Krashen, S. D., \& Terrell, T. D. (1983). The Natural approach: Language acquisition in the classroom. Oxford: Pergamon Press.

Lenneberg, Eric. (1967). The Biological Foundations of Language. New York: John Wiley \& Sons.

Muñoz, C., \& Singleton, D. (2011). A critical review of age-related research on L2 ultimate attainment. Language Teaching, 33(1), 1-35.

Oyama, S. C. (1973). A sensitive period for the acquisition of a second language. Unpublished doctoral dissertation, Harvard University. Shirbagi, N. (2010). An exploration of undergraduate student's motivation and attitudes toward English language acquisition. Journal of Behavioural Sciences, 20(2), 1-15. Retrieved from http://pu.edu.pk/images/journal/doap/PDFFILES/1\%20Englisj\%20language \%20learning V20 No1 10.pdf

Singleton, D. M., \& Ryan, L. (2004). Language acquisition: The age factor. Clevedon: Multilingual Matters. 


\section{Appendix}

Tapescript of the interview.

Q: Describe your learning experience

A: Even if english was given in highschool as a third language (uzbek native, rassian as second) it was not so much interesting to learn in untill my father brought me several audiocassettes with western music which had a lyrics as a paper attachment to that tapes. As I was interested what those music text ment $i$ used to read and translate words and that is how my vocabulary started to grow. After I finished bachelors degree and submitted to masters degree by passing TOEFL exam. At that time a bought TOEFL preparation book written by Cliffs. That book was giving grammar in a very simple and clear style. It took me 2 weeks to read that book through and 2 extra weeks to prepare for exams. That is how I improved my grammar.

Q: Was it difficult for you to learn English? What was it that makes it most difficult for you?

A: learning English was not difficult as I was excided that I can understad words and text which were meaningless for me before, as Chinese now. But it was really hard to learn grammar, later in life I undestood that it was hard to learn grammar because I was learning it from wrong books which were written by russian authors. When I got into UK I realised that I don't understand british accent, it was absolutely different from what I heard on BBC. And I also realised that my speaking is too poor. So it was a hard time for me until I got my speaking and listening improved.

Q: In terms of speaking, listening, reading, and writing, in which aspect do you think you have made most progress since your arrival?

A: In speaking

Q: Do you think you have favourable learning conditions to learn English? 
A: The most favorable conditions for me to learn English was in University, where we had a lecturer who was just some knowledge sharing experience and just having talk with us in English. He didn't know russian or uzbek, so when we didn't understand some words in his speach he explained the meaning in simple words. That was my best and favorite experience learing English.

Q: What obstacles have you experienced in learning English?

A: The major obstical learing English in my life was my school teacher, this is not only my opinion. She had a very bad attitude to me and my schoolmates so I was not interested in her lesson at all. All I leared from her is "once more". That how she thought she will be able to teach us enlish repeating one word again and again. It was too boring

Q: How long do you think it took for you to be able to speak English fairly fluently? What do you consider the best method to improve your oral English? Do you think oral English is better learned through use or by rote?

A: When I got into UK It took me about 3 month to become fluent it english as I had not choice becase was surrounded by british students and lecturers. So I conceder speaking in non native language environment is best way to improve your speaking skills. So for me practice is best way to improve oral language

Q: How would you rate your memory? Are you able to remember what you have learned in class and use it in social contexts? Do you think age is a factor in learning a second language? If yes, in what way?

A: My memory is quite ok as I clearly understand that everybody have problems with memory to some extent. I clearly understand what I'm being taught on lectures and have an ability to share my thoughts and knowledge with others. I'm not sure if age is a factor in learing language, but I can tell that I haven't learned any other language since then, even if I tried to start learing arabic and german. None succeded. 